\title{
Congress grills officials over biosafety boom
}

Critics are questioning whether a multi-billiondollar programme to improve public safeguards against dangerous pathogens is really making the United States safer than it was before.

The criticism surfaced in Washington on 4 October, when members of Congress grilled officials of the Bush administration over the rapid expansion of laboratories that house pathogens such as anthrax and Ebola. The same day, the Government Accountability Office, an investigative arm of Congress, reported that the government wasn't keeping tabs on the number of such labs in operation, or coordinating their regulation.

"Are so many labs doing this research that you actually increase the chances of a catastrophic release of a deadly disease?" asked Bart Stupak (Democrat, Michigan) at the hearing of the House energy and commerce committee. The committee heard testimony from senior officials of the National Institutes of Health (NIH) and the Centers for Disease Control and Prevention (CDC), the agencies that oversee much of the work.

The hearing came three months after the CDC halted research on potential bioweapons agents at Texas A\&M University in College Station, when a lab worker there contracted brucellosis (see Nature 448, 105-106; 2007).
Documents uncovered by Associated Press have since identified more than 100 mishaps ranging from bird flu transmitted to a lab worker by a ferret bite, to missing vials of anthrax.

Critics of the expansion claim that the mishaps indict the entire biosafety research programme. "This work cannot be safely performed in a university or corporate setting," says Richard Ebright, a molecular biologist at Rutgers University in Piscataway, New Jersey.

Before the terrorist attacks of 11 September 2001 and the subsequent anthrax releases that killed five people in the United States, only a few studies of dangerous pathogens were done outside fortress-like government facilities such as the CDC's laboratories in Atlanta, Georgia, and the Army Medical Research Institute of Infectious Diseases in Fort Detrick, Maryland.

But to broaden its knowledge and engage leading scientists, the Bush administration ramped up biosecurity research outside those facilities. In 2001, the National Institute of Allergy and Infectious Diseases - the NIH institute that has led the biosecurity agenda - spent $\$ 41$ million on such work. Last year, it spent \$1.6 billion. And the number of biosafety 4 laboratories studying deadly pathogens without cures has grown from 5 in 2001 to 15 either in operation or being planned today. Currently, 409 labora-

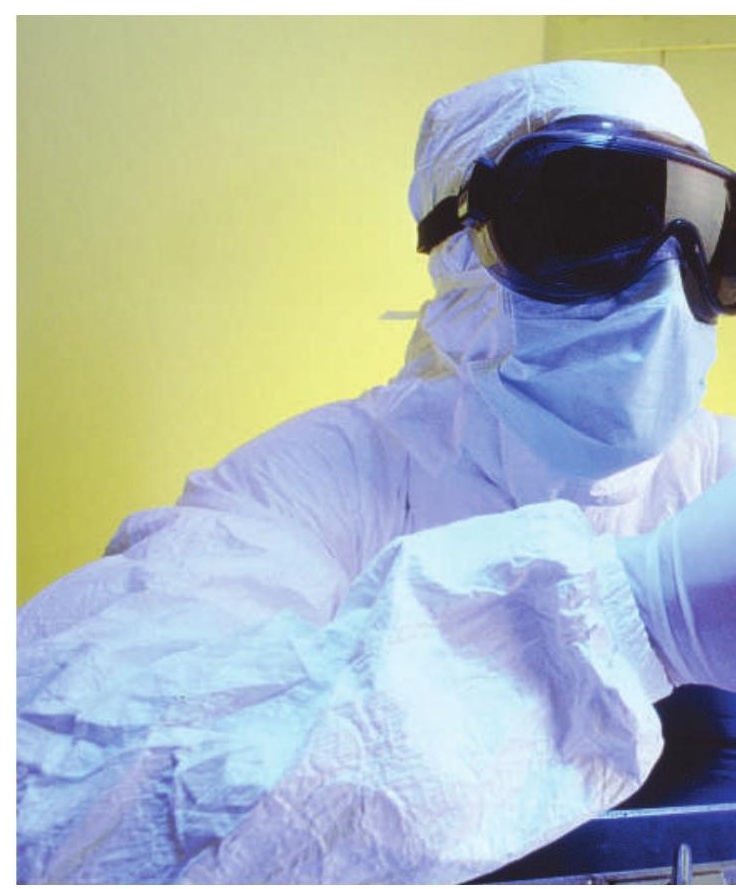

tories staffed by 14,000 people tinker with the various 'select agents' tracked by the CDC.

So far, none of the security lapses is known to have harmed the public, says microbiologist Ronald Atlas, graduate dean at the University of Louisville in Kentucky. But Atlas worries that the government has placed more emphasis on physical security than on training people to handle pathogens safely. "When you work in a lab, you can become complacent," he admits, "and that just can't be allowed today." But he is against the scaling back of pathogen research.

\section{Europe ponders restrictions on life sciences}

European biologists have criticized the idea of a 'two-tier' research publication system floated by the European Commission.

In a 'green paper' published on 11 July, the commission asked whether sensitive biological research should be published twice: a public version without sensitive content and a full-content one for "relevant bio-stakeholders". But several groups have taken issue with the ideas proposed in the discussion document.

The European Biosafety Association (EBSA), which represents people working in biosafety and associated activities, said that it thought the two-tier approach was "unworkable and contrary to scientific freedom".

Similarly, the bioindustry body EuropaBio, based in Brussels, Belgium, said: "Pre-publication review of scientific research and possibly classification of its release raises profound questions for scientific freedom - questions that have been addressed in the nuclear field but not substantially in the life sciences."

Neither group spelled out how it thinks that information on potentially dangerous pathogens, for instance, should be contained. The EBSA, however, suggests that professional associations should develop guidelines on this matter.

$\begin{array}{cl}\text { sounds good, but } & \begin{array}{l}\text { dangerous pathogens, for } \\ \text { instance, should be contained. }\end{array} \\ \text { who is going to be } & \begin{array}{l}\text { The EBSA, however, suggests } \\ \text { that professional associations } \\ \text { should develop guidelines on } \\ \text { the gatekeeper?" }\end{array}\end{array}$

The paper provides no details on how a two-tier publication system might work in practice. John Marks, chief executive of the European Science Foundation, a coalition of European research agencies based in Strasbourg, France, says that the question of who might operate such a system remains unresolved. "In principle it sounds good," he says. "But the question is: who is going to be the gatekeeper?"

The still-unexplained anthrax attacks in the United States in 2001, together with publications such as those describing the creation of a particularly virulent version of mousepox ${ }^{1}$ and the synthesis of an influenza strain containing parts of the 1918 pandemic virus ${ }^{2}$, has led to the consideration of various approaches to control access to some types of biological information (see Nature 441, 388-389; 2006). The green paper was a part of this process, and together with the comments received on it, could eventually lead to European legislation.

As well as the two-tier system of publication, the green paper suggests that 
